\title{
Assumption of Responsibility: Four Questions
}

\author{
DONAL NOLAN ${ }^{*}$
}

\begin{abstract}
Although the assumption of responsibility concept pervades the English law of negligence, its meaning remains hazy and its significance contested. While the courts employ the language of assumption of responsibility on a regular basis, no clear judicial definition of it has emerged. And commentators are divided as to whether assumption of responsibility is a distinct ground on which liability is imposed, or merely a foil for policy arguments - or for another, more general, test for the recognition of duties of care. Matters are complicated by the fact that assumption of responsibility does not fit neatly within the orthodox categories of 'tort' and 'contract', but hovers uncertainly between the two. The aim of this article is to try to bring some clarity to the controversies surrounding assumption of responsibility. Four questions frame the analysis. What does assumption of responsibility mean? When does it matter? Why do we need it? And where does it belong? Although the answers to some of these questions are necessarily tentative, at least one conclusion should become clear, namely that assumption of responsibility is a meaningful and distinctive basis on which to impose negligence liability.
\end{abstract}

Keywords: negligence; duty of care; assumption of responsibility; Hedley Byrne; reliance

\section{INTRODUCTION}

The phrase 'assumption of responsibility' should be familiar to anyone with even a passing knowledge of the modern law of negligence. The underlying principle is an ancient one, ${ }^{1}$ though it is only since the seminal decision of the House of Lords in Hedley Byrne \& Co v Heller and Partners ${ }^{2}$ in 1963 that our courts have imposed negligence liability explicitly on the grounds that the defendant had assumed a responsibility towards the claimant. The tendency of the courts to do this is now more pronounced than ever. The Court of Appeal has, since the turn of the century, employed the concept to justify imposing negligence liability on a parent company for an asbestos-related disease suffered by an employee of a subsidiary, ${ }^{3}$ on the Ministry of Defence for injuries suffered by an soldier who fell off the back of a

\footnotetext{
* I am grateful to Andrew Dickinson, Matt Dyson, Joshua Pike, James Plunkett, Sandy Steel and two anonymous referees for helpful comments on drafts. The usual caveat applies.

1 'It is ancient learning that one who assumes to act, even though gratuitously, may thereby become subject to the duty of acting carefully, if he acts at all' (Glanzer $v$ Shepard 135 NE 275, 276 (Cardozo J)). On the historical underpinnings of the concept, see Paul Mitchell, 'Hedley Byrne \& Co Ltd v Heller \& Partners Ltd (1963)' in Charles Mitchell and Paul Mitchell (eds) Landmark Cases in the Law of Tort (Hart Publishing, 2010). See also Joseph H Beale, 'Gratuitous Undertakings' (1891-1892) 5 Harv L Rev 222.

2 [1963] AC 465 (HL).

${ }^{3}$ Chandler v Cape plc [2012] EWCA Civ 525, [2012] 1 WLR 3111.
} 
lorry after a drunken night on the town, ${ }^{4}$ and on a householder whose friend had fallen out of the householder's loft while working on the entry hatch cover. ${ }^{5}$ And the concept is also of central importance in the law of professional liability, ${ }^{6}$ as is shown by another, very recent, decision of the Court of Appeal in which it was held that an architect's provision of her expertise free of charge to a couple who were her friends had given rise to a duty of care in respect of their purely economic interests. ${ }^{7}$ Furthermore, the recent demise of the general three-stage test for the existence of a duty of care said to be derived from the speech of Lord Bridge in Caparo Industries plc $v$ Dickman ${ }^{8}$ enhances the significance of the concept, by removing from the armoury of the courts a rival approach to the determination of the duty of care issue in the types of case in which it has been used. ${ }^{\text {? }}$

But despite the frequency with which the courts invoke the assumption of responsibility concept, it is difficult to be sure what they mean by it, as different judges seem to have quite different things in mind when they employ the phrase. Judicial ambivalence is mirrored by academic disagreement, as was graphically illustrated by the recent publication of a collection of essays commemorating the fiftieth anniversary of Hedley Byme. ${ }^{10}$ At least four different schools of thought are discernible in the academic writings on assumption of responsibility, in that

${ }^{4}$ Jebson v Ministry of Defence [2000] 1 WLR 2055 (CA).

${ }_{5}$ Biddick (decd) v Morcom [2014] EWCA Civ 182.

${ }^{6}$ See Robinson v PE Jones (Contractors) Ltd [2011] EWCA Civ 9, [2012] QB 44 [74] (Jackson LJ). It is also worth remembering that the liability of health professionals who provide healthcare free of charge under the National Health Service is grounded on assumption of responsibility.

${ }^{7}$ Lejonvarn v Burgess [2017] EWCA Civ 254, [2017] BLR 277.

${ }^{8}$ [1990] 2 AC 605 (HL). I have argued elsewhere that the continued use of the three-stage test is clearly inconsistent with the approach to the duty of care question laid down by Lord Reed in Robinson v Chief Constable of West Yorkshire Police [2018] UKSC 4, [2018] AC 736 and subsequently confirmed in later Supreme Court decisions: see Donal Nolan, 'The Duty of Care After Robinson $v$ Chief Constable of West Yorkshire Police' in Daniel Clarry (ed), The UK Supreme Court Yearbook, Volume 9 (Appellate Press 2019).

9 The tension between the two approaches was particularly apparent in Customs and Excise Commissioners v Barclays Bank plc [2006] UKHL 28, [2007] 1 AC 181. Nor is it an accident that some of the most vocal academic critics of assumption of responsibility are also supporters of the Caparo test, and its central component of 'proximity'. Again, the fact that it is now clear that - at least as far as English law is concerned - those sceptics backed the wrong horse is likely only to strengthen the assumption of responsibility concept in years to come. For particularly explicit comparisons of assumption of responsibility and the Caparo test (favouring the latter), see Kit Barker, 'Wielding Occam's Razor: Pruning Strategies for Economic Loss' (2006) 26 OJLS 289; and John Hartshorne, 'Contemporary Approaches Towards Pure Economic Loss in the Law of Negligence' [2014] JBL 425. Note, however, that there are at least two alternative approaches to the relationship between assumption of responsibility and general duty tests. One is to try to integrate the two, by making the presence of an assumption of responsibility determinative of an element of the general test, such as proximity: see, eg, Brownie Wills v Shrimpton [1998] 2 NZLR 320 (NZCA) 329 (Tipping J); Deloitte \& Touche v Livent Inc (Receiver of) [2017] SCC 63, [2017] 2 SCR 855. And the other is to dismiss assumption of responsibility as yet another vacuous duty concept, along with 'proximity', 'neighbourhood' and the like: see, eg, Caparo (n 8) 627-629 (Lord Roskill). The former approach has the advantage of reducing the uncertainty and incoherence that always results from the use of a general duty test, but it would be far preferable to abandon the general test altogether. As for the latter, it is the central message of this article that assumption of responsibility is, unlike, say, 'proximity', a perfectly meaningful notion.

${ }^{10}$ Kit Barker, Ross Grantham and Warren Swain (eds), The Law of Misstatements: 50 Years on from Hedley Byrne v Heller (Hart Publishing 2015). 
collection and elsewhere: (1) that the concept as employed by the courts ${ }^{11}$ is essentially meaningless, and either a foil for policy arguments or for an alternative, allegedly more meaningful concept, such as 'proximity'; (2) that cases of assumption of responsibility are really just instances of liability in contract, minus consideration; (3) that in the cases where the assumption of responsibility concept is employed no liability should have been imposed at all; and (4) that assumption of responsibility is a distinctive sui generis basis of legal obligation, separate from both core negligence law and the law of contract. Furthermore, as the essays in the anniversary collection make clear, the academic disputation over assumption of responsibility runs deep. There is quite simply no common ground on this issue between scholars such as Bob Hepple, who described assumption of responsibility as 'a discredited fiction' in a Current Legal Problems lecture in 1997, ${ }^{12}$ and scholars such as Robert Stevens, who treats assumption of responsibility as an important source of rights in his book Torts and Rights. ${ }^{13}$

In this article, my goal is to step back from this maelstrom and to try to bring some clarity to the controversies surrounding assumption of responsibility. Four questions frame the analysis. What does assumption of responsibility mean? When does it matter? Why do we need it? And where does it belong? After trying to answer those four questions, I will also highlight three red herrings that in my view have clouded analysis of the concept. The scope of the article is broad: my concern is with all duties of care that arise out of assumptions of responsibility, including in cases of gratuitous bailment and gratuitous agency. ${ }^{14}$ And I should make it clear at the outset that the breadth of the article and constraints of space mean that I am unable to explore all of the interesting questions that are raised by cases of this kind, or to engage in detailed critique of alternative positions. Instead I have chosen to put forward a positive vision of the assumption of responsibility concept, at a relatively high level of generality.

\section{A TRIP TO THE BEACH}

Before I turn to the first of the four questions I want to consider, it will be instructive for us to go on a little journey. Tony Weir famously said of the House of Lords in Hedley Byrne that 'one almost has the feeling that their Lordships had been on a trip to Mount Olympus and perhaps smoked a joint on the bus'. ${ }^{15}$ However,

\footnotetext{
${ }^{11}$ I am grateful to James Plunkett for alerting me to the need for the qualifying words 'as employed by the courts'. As he himself has pointed out (James Plunkett, The Duty of Care in Negligence (Hart Publishing 2018) 137) critics of assumption of responsibility generally accept that there are some, very limited, circumstances in which the concept can serve as an independent justification for negligence liability. However, their critique rests on the claim that the courts routinely abuse the concept by employing it in circumstances where it cannot so serve.

12 Bob Hepple, 'Negligence: The Search for Coherence' [1997] CLP 87, 88.

${ }^{13}$ Robert Stevens, Torts and Rights (OUP 2007).

${ }^{14}$ Needless to say, other kinds of obligations can also arise out of an assumption of responsibility, but since this article is concerned with negligence they are not relevant here. For discussion of these kinds of obligation in relation to bailment, see Andrew Bell, 'The Place of Bailment in the Modern Law of Obligations' in Norman Palmer and Ewan McKendrick (eds), Interests in Goods (LLP 1998) 484.

15 Tony Weir, 'Errare Humanum Est' in Peter Birks (ed), The Frontiers of Liability, vol 2 (OUP 1994) 105 fn 12.
} 
since I know virtually nothing about Greek law, ancient or modern, I am afraid that our trip will need to be within the jurisdiction, and, as we will need our wits about us, no intoxicating substances will be involved.

So let us imagine instead that you take a trip to the English seaside in the height of summer. It is the middle of a heatwave, and the beach is crowded. You settle down for the afternoon, accompanied by your young son and, naturally, your mobile phone. After a few minutes, you fall into conversation with a couple who are sunbathing nearby. A young man wearing a t-shirt that says 'Lifeguard' then appears. He hoists a flag that indicates his presence to those on the beach and takes up a vantage point on a platform from which he can survey the surf. Reassured by this, you then decide that you would like to cool off with a bracing swim (this is England remember). Since the couple you are talking to seem nice, and sensible, you ask them if they would mind keeping an eye on your son and looking after your phone for a few minutes, and they agree to do so. You enter the water, and swim out from the beach until you are well out of your depth. At that point, you have a severe attack of cramp and get into difficulties. You sink beneath the surface, and eventually lose consciousness. An observer on the beach raises the alarm, and another swimmer pulls your head out of the water and begins to bring you back to the shore. Soon the lifeguard arrives and between them they haul you up onto the beach. You are still unconscious, and have stopped breathing. An off-duty doctor who is nearby comes to their assistance and resuscitates you. Someone has called an ambulance, which arrives on the scene within minutes. You have swallowed so much water that the ambulance crew decide to take you to the nearest hospital, where you are admitted as a patient and make a full and rapid recovery. You are eventually reunited with your son and your phone.

Now the first thing that will strike a seasoned negligence hand about this story is that nobody (apart, possibly, from you yourself) has done anything wrong. The couple did not let a stranger steal your phone and kidnap your child. The other swimmer did not abandon the rescue halfway through for no good reason and let you drown. The lifeguard did not ignore your plight because he was busy updating his status on Facebook. The doctor did not break your ribs while trying to get you breathing again. And the ambulance crew did not go to the wrong beach and turn up an hour late. Indeed, the facts would make for a truly terrible exam question, since no torts whatsoever appear to have been committed.

Nevertheless, the story is instructive, since a number of things happen in it which could amount to 'assumptions of responsibility' that alter the legal relationships between those involved. Hence the story of the trip to the beach should be of interest to a tort lawyer even though everybody involved acts impeccably and the ending is, most unusually for tort law, a happy one. ${ }^{16}$ Unfortunately, we will have to leave the beach for now, but we will be returning to it again at various points in the remainder of the article.

\footnotetext{
16 And therein lies an important truth about the nature of tort law, and indeed private law more generally. Naturally, tort lawyers are inclined to focus on liability and litigation, as it is when those are in issue that their services tend to be required. But that can cause us to forget that tort law is in the background of our lives all the time, setting many of the rules by which people in a civilised community co-exist. It would be strange to think of the rules of chess only in terms of their violation. And similarly, it is strange (though also, for various reasons, perfectly understandable) to think of tort law only in terms of wrongs.
} 


\section{WHAT DOES ASSUMPTION OF RESPONSIBILITY MEAN?}

My first question is also the most difficult to answer, because the meaning of the phrase 'assumption of responsibility' is wreathed in doubt. Two central ambiguities can be identified. The first relates to the word 'responsibility', which has a number of quite distinct meanings, as HLA Hart pointed out in an article entitled 'Varieties of Responsibility'. ${ }^{17}$ In the present context, the two meanings of interest to us are what Hart called 'role responsibility' and 'legal liability-responsibility' (hereafter 'legal responsibility'). By the former, Hart meant the (non-legal) responsibility that attaches to a role or the taking on of a task or job. Suppose for example that I agree with my wife that I will put the bins out tomorrow. I am now 'responsible' for putting out the bins, and she is not. This sense of the word need have nothing to do with the law at all. By contrast, what Hart meant by 'legal responsibility' was legal accountability, or exposure to liability. This is what we mean, for example, when we say that an employer is 'responsible' for the torts of its employees. Clearly, when we talk about 'responsibility' in these two senses, we are talking about two quite different things. And yet it is often difficult to know which of these two meanings of the word is intended when judges and scholars talk of 'assumption of responsibility'.

The second ambiguity is apparent not so much from the phrase 'assumption of responsibility' itself, but from the word 'undertaking', which is often used as a synonym for it. ${ }^{18}$ The problem here is that the word undertaking can mean either to promise or give an assurance that you will do something, or to tackle or begin doing something. Hence having undertaken to put the bins out, I am now undertaking the task. Unfortunately, however, it is again sometimes unclear which of these two senses of the word is intended when it is said that negligence liability is based on an undertaking, with the result that it is unclear whether the duty of care arises out of an express or implied promise or assurance which the defendant has made, or simply out of the fact that the defendant has begun performing a task or job of some kind, and has thereby assumed responsibility in the role responsibility sense. ${ }^{19}$

The end result is that when a negligence lawyer talks about an 'assumption of responsibility', she could mean any of three different things: (1) the taking on of a task, including by beginning performance of it ('role' responsibility, and the second sense of 'undertaking'); (2) the acceptance of a legal duty (which is to say, an acceptance of responsibility in the 'legal responsibility' sense); or (3) the giving of a promise or assurance (the first sense of 'undertaking'). Furthermore, it seems to me from reading the cases that judges have ascribed all three of these possible meanings to the phrase, and indeed sometimes have ascribed more than one of these meanings to it in the same judgment.

${ }^{17}$ HLA Hart, 'Varieties of Responsibility' (1967) 83 LQR 346.

18 Both the noun 'undertaking' and the verb 'undertake' feature frequently in Hedley Byrne (n 2): for the noun, see at 492 (Lord Reid), and 529-530, 532-533 (Lord Devlin); and for the verb, see, eg, at 495, 497, 502-503 (Lord Morris), and 528 (Lord Devlin).

${ }^{19}$ Highlighting the historical significance of the ambiguity, see JH Baker, An Introduction to English Legal History (4th edn, Butterworths LexisNexis 2002) 334. And see also PH Winfield, 'Duty in Tortious Negligence' (1934) 34 Col L Rev 41, 55 ('a conveniently ambiguous word'). 
Matters are complicated further by the fact that although the different meanings are distinct, the same action can amount to an assumption of responsibility in more than one of these senses. So, for example, when I tell my wife that I will take the bins out tomorrow, I am both taking upon myself the task of doing so (meaning one), and also giving her an assurance that I will do so (meaning three). Similarly, when I become a trustee of a charity, I am both taking on a task (meaning one again) and accepting a legal duty (meaning two).

Although it looks at this point as though there may be no clear answer to my first question, the deadlock can be broken if we switch our focus to the results of the cases, and ask ourselves what conduct it is that triggers the judicial conclusion that an assumption of responsibility has taken place ('the conduct that engenders the relation', as Cardozo CJ put $\mathrm{it}^{20}$ ). And looking at the cases, it seems clear that by far the most plausible way of characterising the conduct that, at least prima facie, triggers that conclusion is that $A$ bas taken on a task or job for $B$ (ie, meaning one). ${ }^{21}$ And it follows that unless $\mathrm{A}$ has taken on a task or job for $\mathrm{B}$, there is no assumption of responsibility, and any legal duty that the court recognises must rest on a different foundation.

A few examples will help us to see what I mean by this claim. In Henderson v Merrett Syndicates $L t d{ }^{22}$ the defendant underwriting agents took on the task of managing the insurance syndicates of which the claimants were members. In Barrett $v$ Enfield London Borough Council ${ }^{2}$ the local authority took on the task of looking after the claimant when they took him into their care as a baby. In Watson v British Board of Boxing Control ${ }^{4}$ the British Boxing Board of Control took on for the participants the task of ensuring that there were adequate medical facilities at an approved title bout. In Biddick $v$ Morcom ${ }^{25}$ (the case about the loft hatch cover), the defendant took on the task of ensuring that the cover remained locked. In bailment cases, the bailee takes on the task of looking after the goods of the bailor. And so on and so forth.

Perhaps even more illuminating are the cases where this requirement that $\mathrm{A}$ took on a task or job for $\mathrm{B}$ was not satisfied, so that there was no assumption of responsibility. The best such example is White $v$ Jones, ${ }^{26}$ a decision which, properly understood, is arguably the single most illuminating case on the assumption of

\section{${ }^{20}$ HR Moch Co Inc v Rensselaer Water Co 159 NE 896 (NY 1928) 898.}

${ }^{21}$ See, eg, Hedley Byrne (n 2) 497 (Lord Morris) (referring to 'situations in which one person voluntarily or gratuitously undertakes to do something for another person'); and Henderson v Merrett Syndicates Ltd [1995] 2 AC 145 (HL) 186 (Lord Goff) (Hedley Byrne established 'the principle upon which liability may arise in tortious negligence in respect of services (including advice) which are rendered for another'). For a particularly clear judicial use of this test, predating Hedley Byrne, see Davis $v$ Foots [1940] 1 KB 116 (CA) 122, 124 (MacKinnon LJ) ('I do not think there was any undertaking to do work for the plaintiff, 'there is no question of doing a service for the plaintiff or her husband at all'). Note also the parallel with the old assumpsit action, which lay 'where one party undertook to act for the benefit of another and carelessly misperformed' (Mitchell (n 1) 173).

${ }^{22}$ Henderson (n 21).

23 [2000] 2 AC 550 (HL).

24 [2001] QB 1134 (CA).

25 Biddick (n 5).

${ }^{26}$ [1995] 2 AC 207 (HL). 
responsibility concept. ${ }^{27}$ In White, a majority of the House of Lords held that an intended beneficiary under a will was entitled to recover damages from the testator's solicitors, if, by reason of their negligence, the testator's intention to benefit the claimant had not been carried into effect. Now it seems perfectly clear that the liability in White does not rest on an assumption of responsibility basis, since although the defendant had agreed to prepare the will, he had not taken on this task for the beneficiaries (the claimants), but for the testator. What is more, both Lord Goff, in the leading majority speech, and Lord Mustill in the leading dissenting speech, make this point quite explicitly. According to Lord Goff, there was 'great difficulty' in holding that a solicitor assumed any responsibility towards the intended beneficiary of a will since 'in the absence of special circumstances', the relevant work 'cannot be said to have been undertaken for the intended beneficiary'. ${ }^{28}$ Hence his conclusion that the assumption of responsibility towards the testator in the case should be 'held in law' to extend to the intended beneficiaries ${ }^{29}$ (in other words, although in fact there was no assumption of responsibility towards the claimants, there should be 'deemed' to be one). Similarly, Lord Mustill emphasised the fact that the solicitor had not undertaken the task of drawing up the will 'for the beneficiaries' (his emphasis), but for the testator, and said that the 'cardinal feature' of the Hedley Byme case was that 'the defendants undertook the job [in that case, of providing a credit reference] for the plaintiffs. ${ }^{30}$

A recent decision of the Supreme Court, Banca Nazionale del Lavoro SPA v Playboy Club London $L t d{ }^{31}$ rests on precisely the same kind of reasoning. In this case a bank provided a credit reference in respect of one Hassan Barakat to a company called Burlington Street Services. The company was acting on behalf of the Playboy Club, a casino frequented by Barakat, but the bank did not know this. Since the bank did not assume any responsibility to the Playboy $\mathrm{Club},{ }^{32}$ no duty of care was owed to the club in respect of the reference. ${ }^{33}$ This reasoning also explains why a doctor carrying out a pre-employment health assessment for a company, or instructed by an insurer to examine an applicant for life insurance, owes no duty of care to the subject of the assessment or examination beyond the core Donoghue $v$ Stevenson ${ }^{34}$ duty not

27 Other useful negative examples include Customs and Excise Commissioners (n 9), where, as Lord Mance said (at [94]), it was 'difficult in any meaningful sense to speak of the bank as having voluntarily assumed responsibility even for the task in relation to which it was allegedly negligent, let alone responsibility towards the commissioners for the task'.

${ }^{28}$ White (n 26) 262. See also at 268.

29 ibid 268.

30 White (n 26) 290. See also at 251 (Lord Keith).

31 [2018] UKSC 43, [2018] 1 WLR 4041.

32 See ibid [16] (Lord Sumption).

${ }^{33}$ For criticism of some aspects of the Supreme Court's reasoning, albeit within an overall framework similar to mine, see Julius AW Grower and Orestis F Sherman, 'Equivalent to Contract? Confronting the Nature of the Duty Arising under Hedley Byrne v Heller' (2019) 135 LQR 177. Of course, there will be borderline cases where opinions can reasonably differ on the question of for whom the work was taken on. For a helpful discussion, see Keith Stanton, 'Hedley Byrne and Heller. The Relationship Factor' [2007] Professional Negligence 94.

34 [1932] AC 562 (HL). 
negligently to injure through positive conduct. ${ }^{35}$ And it may even explain why it is that, unlike the ambulance service, ${ }^{36}$ the police ${ }^{37}$ and fire brigade ${ }^{38}$ generally owe no duty of care to individuals in emergency situations, on the footing that when responding to an emergency call they act not for the benefit of particular individuals, but the public as a whole. ${ }^{39}$

Although I am wary of getting mired in the case law, I should at least acknowledge that there at least two important decisions at the highest level which are difficult to reconcile with this analysis. The first is Smith v Eric $S$ Bush, ${ }^{40}$ which was not decided on an assumption of responsibility basis, but which is nevertheless now considered to be a possible application of the Hedley Byrne principle. In the first of the two appeals (Smith), it was arguable that the surveyor had in fact taken on the job of surveying the property both for the bank and for the claimants (the prospective purchasers of the house), not least because the surveyor knew that the claimants had paid for the survey, and that a copy of his report would be passed on to them by the bank. However, in the second of the two appeals (Harris v Wyre Forest District Council), it was not really plausible to say that the council surveyor assumed any responsibility towards the prospective purchasers, since the mortgage application form stated that the valuation was intended solely for the information of the local authority, and it was never intended that it be shown to the claimants (as indeed it was not). ${ }^{41}$ If I am correct in my evaluation of the two appeals, then it follows that while the outcomes in the Court of Appeal in both cases were consistent with an assumption of responsibility analysis, this was not so in the House of Lords in relation to the second appeal. ${ }^{42}$

35 See X (minors) v Bedfordshire County Council [1995] 2 AC 633 (HL) 752 (Lord Browne-Wilkinson) (life insurance example); Kapfunde v Abbey National plc [1998] IRLR 583 (CA) (pre-employment health check). See also the decision in $X$ (minors) that social workers and psychiatrists instructed by a local authority to report on suspected victims of child sexual abuse did not assume any general professional duty of care to the children in question.

36 Kent v Griffiths [2001] QB 36 (CA).

${ }^{37}$ Michael v Chief Constable of South Wales Police [2015] UKSC 2, [2015] AC 1732.

38 Capital and Counties plc v Hampshire CC [1997] QB 1004 (CA).

${ }^{39}$ For general discussion, see Donal Nolan, 'The Liability of Public Authorities for Failing to Confer Benefits' (2011) 127 LQR 260, 280-281. A distinction along these lines was adverted to by StuartSmith LJ in Capital and Counties (n 38) at 1036-37, and by Lord Woolf MR in Kent (n 36) at 52-53, and was explicitly endorsed and employed in Furnell v Flaherty [2013] EWHC 377 (QB) [64] (Turner J). However, its application is not always straightforward: see, eg, Sherratt $v$ Chief Constable of Greater Manchester Police [2018] EWHC 1746 (QB), [2019] PIQR P1 [83] (King J) (arguing that in some circumstances the police, like the ambulance service, act for the benefit of a particular individual).

40 [1990] 1 AC 831 (HL).

${ }^{41}$ A comparison of the facts of the appeal with the discussion of Robinson v National Bank of Scotland 1916 SC (HL) 154 in Lord Devlin's speech in Hedley Byrne (n 2) 532-533 is particularly revealing.

42 In Williams v Natural Life Health Foods [1998] 1 WLR 830 (HL), Lord Steyn said (at 837), in a section of his speech defending the assumption of responsibility concept against academic criticism, that both Smith $v$ Bush and White v Jones had been 'decided on special facts'. And for implicit disapproval of the decision in the Wyre Forest appeal in particular, see also Scullion v Bank of Scotland plc [2011] EWCA 693, [2011] 1 WLR 3212 [48] (Lord Neuberger MR). 
And the other case that is difficult to explain on my view of the law is Spring $v$ Guardian Assurance, ${ }^{43}$ for while in general I think that it is plausible to say that an employer who undertakes to provide a reference for a former employee is taking on the task for the employee, ${ }^{44}$ on the facts of Spring the request came from the prospective employer, rather than the former employee, and there was no suggestion that the provision of a reference was something that the defendant had agreed to do on the employee's behalf. ${ }^{45}$ Hence it seems to me that the decision to impose liability in Spring may better be explained on an alternative basis (such as an implied term of the contract of employment).

Returning to the three different possible meanings of the phrase 'assumption of responsibility', in cases where A has taken on a task or job for B, A may or may not have done so by making a promise or giving an assurance to $\mathrm{B},{ }^{46}$ but for present purposes that seems to me to be irrelevant. What matters is that $\mathrm{A}$ has taken on the task, not how $\mathrm{A}$ has done so. ${ }^{47}$ It follows that an assumption of responsibility does not necessarily involve any communication from A to B, and hence that the off-duty doctor may be assuming a responsibility to you on the beach (and thereby coming under a positive obligation to assist you ${ }^{48}$ ) even though you are unconscious. The apparent equation of assumption of responsibility with a 'promise' or 'assurance' in Lord Toulson's brief discussion of the concept in Michael v Chief Constable of South $W$ ales Police was therefore contrary to principle. ${ }^{49}$

The resolution of the ambiguity between the two meanings of responsibility is more challenging. Here the best interpretation of the cases is that although in theory both are required, when $\mathrm{A}$ takes on the task or job for $\mathrm{B}$ (role responsibility), $\mathrm{A}$ will be presumed to be implicitly taking on the duty to perform that task with due care, and that the law generally attaches legal responsibility to that implicit undertaking to take care, unless there is a good reason why it should not do so. ${ }^{50}$ And there are at least

43 [1995] 2 AC 296 (HL).

${ }^{44}$ See the analysis of Lord Goff in Spring (n 43) at 319.

45 See similarly, Allan Beever, Rediscovering the Law of Negligence (Hart Publishing 2007) 316-319.

46 This would, for example, have been the case in Wilkinson v Coverdale (1793) 1 Esp 75, 170 ER 284, had the defendant in fact promised to procure insurance cover for the plaintiff.

${ }^{47}$ Much depends on the context, it seems. The obligations of a gratuitous bailee arise only when A actually takes possession of B's property; a promise to look after it is not enough. Conversely, in gratuitous agency cases, the agent's obligations may arise simply by virtue of A saying that she will arrange the insurance, etc for $\mathrm{B}$. In the latter situation, attaching significance to the promise/assurance may seem to contradict the principle that promises are not binding without consideration, but this is not the case. The law is not saying here that A must keep the promise: rather, that she must exercise reasonable care in carrying out the task she promised to perform. And besides, the better view is that in such a case A is free to renege on the promised performance altogether, as long as B is left no worse off: see, eg, US Restatement, Second, Agency (1958) \& 378, comment b.

48 Though cf the claim by Stuart-Smith LJ in Capital and Counties (n 38) at 1035 that in the absence of a doctor-patient relationship no special duty is assumed, so that the only obligation of an off-duty doctor who assists a road accident victim is not to make things worse (and see similarly Watson (n 24) [47] (Lord Phillips MR)).

${ }^{49}$ Michael (n 37) [138].

50 The assumption of legal responsibility is therefore 'an explanatory construction, not a fact which must be separately found' (JA Weir, 'Liability for Syntax' [1963] CLJ 216, 217). As to why the law might approach the issue in this way, see AJE Jaffey, 'Contract in Tort's Clothing' (1985) 5 LS 77, 
five reasons that the courts have given for not recognising a legal duty of care in such a case: (1) that A took on the task or job in an informal or social context; ${ }^{51}$ (2) that A expressly disclaimed legal responsibility (as in Hedley Byrne itself); (3) that the recognition of legal responsibility would be inconsistent with the terms of a contract between $\mathrm{A}$ and $\mathrm{B} ;{ }^{52}$ (4) that $\mathrm{A}$ and $\mathrm{B}$ deliberately structured their commercial relationship in such a way as to avoid direct liability inter se, so that an assumed duty of care would have the effect of 'short-circuiting' this contractual structure ${ }^{53}$ and (5) that recognition of a legal duty of care would be contrary to public policy. ${ }^{54}$ Note that these reasons are not necessarily exhaustive, and that they do not necessarily have equal force in all contexts: the informal nature of the undertaking, for instance, seems not to be a bar to an assumption of legal responsibility in personal injury cases. $^{55}$

The analysis here is consistent with the fact that the cases abound with statements to the effect that 'the assumption of the task ... was the assumption of a duty [of care]. ${ }^{56}$ In Hedley Byrne itself, for example, Lord Reid repeatedly used the language of inference, as when he said that in this case the question is whether an undertaking to assume a duty to take care can be inferred' ${ }^{57}$ while Lord Devlin repeatedly used the terminology of implication. ${ }^{58}$ For the law to treat the taking on a task for another as impliedly involving an undertaking to perform that task with due care is hardly controversial. By saying that they will look after your phone and child it is clear that the couple on the beach are implicitly undertaking to exercise due care in doing so. And indeed such an interpretation of their conduct is consistent with the way in which terms are implied into contracts; hence the duties of care that are routinely implied into professional services contracts, employment contracts and so forth. ${ }^{59}$

102. And for a similar analysis to that in the text, see Bruce Feldthusen, Economic Negligence (6th edn, Carswell 2012) 57-62.

51 See Hedley Byrne (n 2) 482-483 (Lord Reid).

52 Henderson (n 21) 194-195 (Lord Goff). See, eg, Robinson v PE Jones (Contractors) Ltd (n 6) [84] (Jackson LJ).

${ }^{53}$ Henderson (n 21) 195 (Lord Goff). See also Muirbead v Industrial Tank Specialities Ltd [1986] QB 507 (CA); Simaan General Contracting Co v Pilkington Glass Ltd (No 2) [1988] QB 758 (CA) 781 (Bingham LJ), 785 (Dillon LJ); and RM Turton \& Co Ltd (in liq) v Kerslake and Partners [2000] 3 NZLR 406 (NZCA). For a defence of this principle, see Jaffey (n 50) 92, but compare Thomas J's powerful dissenting judgment in the New Zealand case.

${ }^{54}$ Hence the immunity that barristers used to enjoy in respect of their conduct of litigation (Rondel $v$ Worsley [1969] 1 AC 191 (HL)), abolished in Arthur JS Hall \& Co Ltd v Simons [2002] 1 AC 615 (HL).

55 See, eg, Biddick (n 5), where the assumption of responsibility was in a very informal context.

56 Glanzer (n 1) 276 (Cardozo J). See similarly Cassidy v Ministry of Health [1951] 2 KB 343 (CA) 359360 (Denning LJ); Gilchrist Watt \& Sanderson Pty Ltd v York Products Pty Ltd [1970] 1 WLR 1262 (PC) 1267-68 (Lord Pearson) (discussing bailment); Henderson (n 21) 205 (Lord Browne-Wilkinson); and Biddick (n 5) [53] (McCombe LJ).

${ }^{57}$ Hedley Byrne (n 2) 492.

58 See, eg, ibid 532 ('an implied undertaking to accept responsibility').

59 See also Plunkett (n 11) 137 (referring to the 'officious bystander' test). And for an argument to similar effect with regard to fiduciary duties, see James Edelman, 'When do Fiduciary Duties Arise?' (2010) 126 LQR 302. On implication in general, see Joseph Raz, 'Promises in Morality and Law' (1982) 95 Harv L Rev 916, 932. In theory it is possible for A to make it clear to B that she is not undertaking to exercise reasonable care, in which case clearly no special duty of care (legal or moral) will arise, although the relevant words or conduct might instead be understood as merely lowering the implied standard of care. This seems to me to be conceptually distinct from a disclaimer of legal 
And as for the law attaching legal responsibility to the implicit undertaking to exercise reasonable care unless there is a good reason not to do so, this defeasibility analysis is consistent with the statement by Lord Goff in the Spring case that in the context under consideration, there is no question of the circumstances ... being, for example, so informal as to negative an assumption of responsibility by the employer. ${ }^{60}$

Again, the analogy of contract law is helpful, since the best way of understanding what is going on with regard to legal responsibility here is to consider the contract doctrine of 'intention to create legal relations' ${ }^{61}$ Although in theory that doctrine is a positive requirement of a binding contract, in practice it operates as a negative condition, such that an agreement supported by consideration will be held to be legally binding unless either the parties have expressly said that it was not intended to be, ${ }^{62}$ or it was made in an informal or domestic setting. ${ }^{63}$ This analogy also helps us to understand why it is that these countervailing considerations prevent any legal duty from arising, rather than excluding a duty that already exists, as was emphasised in Hedley Byrme ${ }^{64}$ and has been confirmed in later judicial analysis of disclaimers in this type of case. ${ }^{65}$

Although that concludes the core of my answer to the first question, before I move on I want to identify some further distinctive features of the assumption of responsibility concept, and then to respond to two possible objections to my analysis of it.

Enough has I hope been said to demonstrate that the obligations of care which flow from an assumption of responsibility are distinguishable from what we might call 'core negligence' obligations - which is to say those that we automatically owe to others simply by virtue of our presence in the jurisdiction - since they come into being only if we take on a task for another person. There are at least three other distinct features of these obligations. The first is that they are not owed by all of us to everyone else. Rather, the assumption of responsibility doctrine comes with its own form of privity rule, which, like the contractual privity rule, cuts both ways. Hence, only those for whom the task or job is undertaken can rely on the assumption

responsibility - where a moral duty of care may nonetheless arise - though legally nothing turns on the distinction, and it is not clearly articulated in the case law.

60 Spring (n 43) 319 (emphasis added).

${ }^{61}$ See also Simon Whittaker, 'The Application of the 'Broad Principle of Hedley Byrne' as Between Parties to a Contract' (1997) 17 LS 169, 176; Beever, Rediscovering the Law of Negligence (n 45) 291.

${ }^{62}$ See, eg, Jones $v$ Vernon Pools Ltd [1938] 2 All ER 626 (KBD).

${ }^{63}$ See, eg, Balfour v Balfour [1919] 2 KB 571 (CA). In language strongly reminiscent of that used in the contract context, Stocker LJ said in the assumption of responsibility case of Chaudhry v Prabhakar [1989] 1 WLR 29 (CA) (at 36) that in the absence of other factors giving rise to [a duty of care], the giving of advice sought in the context of family, domestic or social relationships will not in itself give rise to any duty in respect of such advice'.

${ }^{64}$ Hedley Byrne (n 2) 492 (Lord Reid), 504 (Lord Morris), 511 (Lord Hodson), 533 (Lord Devlin), 540 (Lord Pearce).

65 See, eg, McCullagh v Lane Fox \& Partners Ltd [1996] PNLR 205 (CA) 223 (Hobhouse LJ); Barclays Bank plo v Grant Thornton UK LLP [2015] EWHC 320 (Comm), [2015] 2 BCLC 537 [41] (Cooke J). It follows that, as their Lordships made clear in Hedley Byrne, such a disclaimer should not necessarily be subject to the same restrictions as are operative where a defendant seeks to exclude or limit a core negligence duty, such as interpretation contra proferentem. 
of responsibility, as the Banca Nazionale del Lavoro case illustrates. But equally, only those who in fact undertake the task or job for the claimant are burdened by the assumption of responsibility. This explains why, for example, the managing director of the company in Williams $v$ Natural Life Health Foods ${ }^{66}$ owed no duty of care to the claimant franchisees, since it was the company that had taken on the task for the franchisees and not the director personally. ${ }^{67}$ And it also explains why it is that a subbailee only comes under a positive obligation to the original bailor if the sub-bailee has notice of the head bailment. ${ }^{68}$ As was rightly said by Lord Sumption in the Banca Nazionale del Lavoro case, the relational aspect of the duties that arise out of an assumption of responsibility is one of the concept's fundamental characteristics. ${ }^{69}$

The second distinctive feature of the obligations that flow from an assumption of responsibility is that the duty in question is in general not merely a duty to take care, but a duty to ensure that care is taken, or in other words a 'non-delegable duty'. This is apparent from the leading case on non-delegable duties, Woodland v Essex County Council, $^{70}$ where Baroness Hale said that the reason why a hospital or school is liable for the negligence of a nurse or teacher, regardless of whether they are an employee of the hospital or school, is that 'the hospital has undertaken to take care for the patient, and the school has undertaken to teach the pupil'. ${ }^{71}$ And the same rule applies in other types of case where assumed duties of care are recognised, such as employment and bailment relationships. ${ }^{72}$ It is also important to note the way in which in these cases the defendant's liability for the negligence of a third party connects back to the idea of assumption of responsibility as taking on a task or job for another person. For liability attaches only to negligence in the performance of the task undertaken by the defendant and delegated to the third party, ${ }^{73}$ and the nondelegable duty is owed only to the person for whom the task was undertaken.

And the final distinctive feature of the obligations of care that arise out of assumptions of responsibility is the fact that, unlike in core negligence law, the defendant can expressly or impliedly tailor the scope or content of the duty, in three different ways: (1) by making it clear for whom the task or job is being done; (2) by delimiting the scope of the task or job itself; ${ }^{74}$ and (3) by calibrating the standard of

${ }^{66}$ [1998] 1 WLR 830 (HL).

${ }^{67}$ See also the illuminating discussion in Trevor Ivory Ltd v Anderson [1992] 2 NZLR 517 (NZCA).

${ }^{68}$ See KH Enterprise (cargo owners) v Pioneer Container (owners), The Pioneer Container [1994] 2 AC 324 (HL) 341 (Lord Goff). Hence, for example, in the beach story, if after taking possession of your phone the couple had asked another beachgoer to look after it, then the other beachgoer would only come under a positive obligation to you if they were told that it was your phone (and that therefore, in a sense, they were taking on the task of minding the phone for you).

${ }^{69}$ Banca Nazionale del Lavoro (n 31) [7].

70 [2013] UKSC 66, [2014] AC 537.

71 ibid [34].

72 See further, Stevens (n 13) 114-123.

${ }^{73}$ Woodland (n 70) [23] (Lord Sumption).

74 See, eg, Wattleworth v Goodwood Road Racing Co Ltd [2004] EWHC 140 (QB), [2004] PIQR 25 (assumption of responsibility by Motor Sports Association limited to structure of course, safety barriers etc); Calvert v William Hill Credit Ltd [2008] EWCA 1427, [2009] Ch 330 [47] (Sir Anthony May P) (responsibility assumed by defendants was not to prevent the claimant from gambling, but 'not to allow him to place telephone bets with them'); Biddick (n 5) [42] (the defendant 'assumed 
care against which the defendant's performance of the job or task will be measured, which is determined, as the cases show us, by the skill or expertise that she 'holds herself out' as possessing. ${ }^{75}$ The tailoring of the scope or content of the duty is based on an objective interpretation of A's words or conduct, ${ }^{76}$ taking into account all the circumstances of the case. ${ }^{77}$

The ability of the person assuming responsibility to tailor the scope of their obligation provides a straightforward explanation for the rule laid down in Caparo Industries $v$ Dickman that in a negligent misstatement case, it must be shown that $\mathrm{A}$ knew that his statement would be communicated to B, 'either as an individual or as a member of an identifiable class, specifically in connection with a particular transaction or transactions of a particular kind'. ${ }^{78}$ Suppose that B asks A, an expert on white goods, which dishwasher B should buy, and A replies that B should buy a model manufactured by Bosch. In so doing, $A$ is taking on the task of advising $B$ about dishwasher purchase, and any duty of care is so limited. If $\mathrm{B}$ subsequently passes on A's advice to C, C is owed no duty by A, as A did not take on the task for $\mathrm{C}$, but for B. And if B buys shares in Bosch as a result of A's advice, A's duty to B does not extend to the investment decision, since $A$ did not take on the task of giving B investment advice. Elaborate policy-based explanations of the Caparo limits in terms of indeterminate liability and so forth are unnecessary. ${ }^{79}$ They are inherent in the concept of assumption of responsibility itself. ${ }^{80}$ Similarly, the failure to appreciate the significance of the distinction between core and assumed obligations causes commentators to tie themselves into knots when trying to reconcile the refusal to lower the standard of care for a learner driver in Nettleship $v$ Weston ${ }^{81}$ (a core Donoghue v Stevenson case) with the standards of care of those who hold

responsibility, not for bearing [the claimant's] weight if he happened to fall on the latch cover, but in undertaking to ensure that the latch remained closed'). See also the very particular formulation of the scope of the duty in Lejonvarn $(\mathrm{n} 7)$ at [111]. Where the parties are in a contractual relationship, the scope of the task or job will usually be discernible from the contract (for example, a solicitor's retainer).

75 See, eg, Phillips $v$ William Whiteley Ltd [1938] 1 All ER 566 (KBD). See also the calibration of the standard of care by reference to the different types of medical practitioner (eg, Maynard $v$ West Midlands RHA [1984] 1 WLR 634 (HL)). The same principle applies in cases of gratuitous agency (see GHL Fridman, The Law of Agency (7th edn, Butterworths, 1996) 160-161), and in gratuitous bailment cases, the standard of care is calibrated by reference to 'all the circumstances of the deposit' (Andrew Burrows (ed), English Private Law (3rd edn, OUP 2013) para 16.36; see further, Bell (n 14) 475-477). The different manners of limitation of the duty may blend into each other. Suppose that in the beach example, a person in a wheelchair had agreed to look after your child. The obvious fact of the person's disability could be interpreted as (implicitly) limiting the scope of the task or alternatively as bearing on the calibration of the standard of care. And the same could be said of the off-duty doctor who intervenes in an emergency situation, and who obviously lacks adequate equipment, may have limited expertise and so on.

${ }^{76}$ See, eg, Banca Nazionale del Lavoro (n 31) [24] (Lord Mance).

77 See Gold v Essex County Council [1942] 2 KB 293 (CA) 301 (Lord Greene MR).

78 Caparo (n 8) 621 (Lord Bridge). See similarly at 637-638 (Lord Oliver).

79 See, eg, Hercules Managements Ltd v Ernst \& Young [1997] 2 SCR 165 [28] (La Forest J). An alternative justification sometimes given for such limits is that reliance on a statement made for a different purpose, or to a different person, is for that reason unreasonable. However, as Beever points out, this claim is as misguided as the similar arguments criticised below, text following $\mathrm{n}$ 119: Allan Beever, 'The Basis of the Hedley Byrne Action', in Barker et al (n 10) 108.

80 See Customs and Excise Commissioners (n 9) [35] (Lord Hoffmann).

81 [1971] 2 QB 691 (CA). 
themselves out as having special skills - such as doctors - in cases where the duty arises out of an undertaking. Again, a proper appreciation of the significance of assumption of responsibility offers a simple explanation for the approaches adopted by the courts in the two different types of case.

Let us finally turn to two possible objections to my analysis. The first is that if ultimately it is the law that decides whether legal responsibility arises, then the liability is in truth imposed by law, rather than assumed by the defendant, and so the idea that it rests on an assumption of responsibility is a 'fiction'. ${ }^{82}$ This objection can be dismissed quickly. All legal obligations are ultimately imposed by law; otherwise they would not be legal obligations. So this in no way undermines the claim that assumption of responsibility is a distinctive source of obligation, or at least no more so than it does the claim that contractual obligations are.

The second objection is that, if by 'assumption of responsibility' the law means only 'taking on a task', then the concept is not a distinctive source of legal obligation, since (it is said) we could just as easily say that a car driver's duty of care towards other road users is grounded in their taking on the task of driving their car. ${ }^{83}$ This objection also fails, for three reasons. First, my claim is not that assumption of responsibility means only taking on a task, but that, by taking on a task for B, A is in general treated as assuming a legal responsibility to exercise due care in the performance of that task (although, unlike in the car case, this responsibility can be avoided by a disclaimer etc). Secondly, the three additional distinctive features of assumption of responsibility that I have identified - its relational quality, the nondelegable nature of the duty, and the ability of the defendant expressly or impliedly tailor the scope of the obligation - are all missing in the case of the car driver's duty. And thirdly, and most fundamentally, the objection rests on a mistaken premise, which is that it is only when the driver gets behind the wheel of the car that their duty of care towards other road users arises. In fact, with one or two very narrow exceptions, each and every one of us owes a general duty not to cause others personal injury or property damage through our negligent positive conduct, an obligation which arises either when we are born, or when we move into the jurisdiction. By getting into my car and driving down the street, I may make it more likely that I will breach that duty than if I stay at home and watch Eastenders, but the duty is not the result of my action, any more than my duty not to lie (as imposed by the tort of deceit) is the result of my deciding to speak.

By contrast, when a duty of care is based on an assumption of responsibility it is the result of something that the defendant has done, namely taking on a task or job for the claimant. And the fact that the duty is not automatic, but the result of something the defendant has done is one of the things that marks out assumption of responsibility as a distinctive basis for the imposition of negligence liability. Had the couple in the beach story refused to accept responsibility for your child, or refused to take possession of your phone, their legal obligations would have remained the same as before. They could have been liable for injuring your child, or smashing your phone, but they would have owed no duty to protect either. And this would also have been

\footnotetext{
82 See, eg, Hepple (n 12).

${ }^{83}$ For examples of this kind of argument, see, eg, Customs and Excise Commissioners (n 9) [37]-[38] (Lord Hoffmann); and Kit Barker, 'Unreliable Assumptions in the Law of Negligence' (1993) 109 LQR 461, 474.
} 
the case if, for example, you had slipped your phone into their beach bag without their consent. ${ }^{84}$ Having taken on those tasks, however, their obligations changed. It was their conduct that brought into being the new legal relation.

\section{WHEN DOES ASSUMPTION OF RESPONSIBILITY MATTER?}

Happily, my second question is a good deal more straightforward to answer than the first, although not without its own controversies. Resolving those controversies would require a closer study of the case law than is possible here, so instead I will content myself with flagging up the situations in which the courts have employed the assumption of responsibility concept to justify imposing a duty of care in negligence. There are three distinct ${ }^{85}$ types of case where this phenomenon is observable: cases involving pure economic loss, omissions cases and deliberate intervening conduct cases. In all these categories of case, the general rule in English law is that there is no duty of care, but such a duty will be owed if there is a relevant assumption of responsibility of the defendant towards the claimant. ${ }^{86}$

Hence, in the beach story, although the doctor who helped to resuscitate you was free (as a matter of tort law anyway) to do nothing to help you, because she chose to intervene a duty of care arose, which was not limited to not making things worse, but which required her to take reasonable steps to improve your situation. ${ }^{87}$ In the case of an established doctor-patient relationship, the same is of course also true, quite regardless of contract, ${ }^{88}$ and more generally the assumption of responsibility principle has been said to embrace the relationships 'in which a duty to take positive action typically arises', including school and pupil and employer and employee. ${ }^{89}$

Similarly, before they took possession of your phone, the couple had no duty to protect it from the criminal activity of third parties. Had they seen a thief steal it from your bag while you were looking the other way, they would have been at liberty to do and say nothing. However, when they took possession of the phone from you,

84 A person cannot, 'without his knowledge and consent, be considered as a bailee [of property]': Lethbridge v Phillips (1819) 2 Stark 544, 545; 171 ER 731, 731 (Abbott CJ). An 'involuntary bailment' is therefore 'a contradiction in terms': Bell (n 14) 468.

${ }^{85} \mathrm{I}$ emphasise this because of the unfortunate tendency not to distinguish properly (or even at all) between the omissions question and the intervening conduct question. The fact that the two issues often arise on the same facts does not make them the same issue.

${ }^{86}$ For a helpful discussion of the interaction between the assumption of responsibility concept and the category-based approach our courts generally take when dealing with notional duty questions, see Plunkett (n 11) 139-144.

${ }^{87}$ For the general principle that an assumption of responsibility may give rise to positive obligations, see, eg, Gorringe v Calderdale MBC [2004] UKHL 15, [2004] 1 WLR 1057. Good examples include Welsh v Chief Constable of the Merseyside Police [1993] 1 All ER 692 (QBD); Barrett v Ministry of Defence [1995] 1 WLR 1217 (CA); Costello v Chief Constable of the Northumbria Police [1999] 1 All ER 550 (CA); Watson (n 24); Chandler (n 3); and Biddick (n 5).

88 Hence a wife or child could historically sue for the negligence of a surgeon employed by a husband/father: see, eg, Pippin v Sheppard (1822) 11 Price 400, 147 ER 512 (wife); Gladwell v Steggall (1839) 5 Bing NC 733, 132 ER 1283 (daughter). As Erskine J said in the latter case (at 737, 1284), 'the substance of the issue is, that the Defendant was employed to cure the Plaintiff; not, that he was employed by the Plaintiff.

${ }^{89}$ Michael (n 37) [100] (Lord Toulson). 
an obligation to safeguard it arose..$^{90}$ And note that this obligation to protect the claimant against deliberately harmful conduct can even extend to the conduct of the claimant herself, which is the best explanation for the decision in Reeves v Metropolitan Police Commissioner ${ }^{91}$ that the police were liable for negligently failing to prevent a vulnerable prisoner from committing suicide.

As for economic loss, ever since Hedley Byme it has been clear that pure economic loss may be recoverable in negligence where there was a prior assumption of responsibility by the defendant towards the claimant. In the years following Hedley Byme, assumption of responsibility was thought to be limited in this context to cases of negligent misstatement, but one consequence of Lord Goff's reformulation of the doctrine in the 1990s was its extension to the negligent performance of a service in the Henderson case. This generalisation of the principle helped to put our law of professional negligence on a more rational footing, which can be contrasted with the way in which some other common law systems continue, for no good reason that I can see, to treat negligent misstatements as a separate category of duty case. ${ }^{92}$

While there is surely no doubt that assumption of responsibility plays an important role in the duty enquiry in these three types of case, there is less agreement about the extent of its significance. The better view seems to be that Lord Goff was right to say in White $v$ Jones that 'as a general rule', no action lies in negligence for pure economic loss apart from cases of assumption of responsibility. ${ }^{93}$ Admittedly, that statement is difficult to square with the speeches in the House of Lords in Customs and Excise Commissioners v Barclays Bank, ${ }^{44}$ but there was precious little consistency in the analysis of the significance of assumption of responsibility in that case, ${ }^{95}$ and in recent Supreme Court decisions on economic loss the concept has been regarded as

${ }^{90}$ See Mitchell v Glasgow City Council [2009] UKHL 11, [2009] 1 AC 874 [23] (Lord Hope), [76] (Lady Hale), [82] (Lord Brown). See, eg, Stansbie v Troman [1948] 2 KB 48 (CA); and Swinney v Chief Constable of the Northumbria Police [1997] QB 464 (CA).

${ }^{91}$ [2001] AC 360 (HL). See also Kirkham v Chief Constable of the Greater Manchester Police [1990] 2 QB 283 (CA), a case where, unlike in Reeves, liability was expressly founded on an assumption of responsibility analysis.

92 As Tony Honoré said in his brilliant 1965 article on Hedley Byrne, 'the distinction between verbal and non-verbal means of doing mischief is not of fundamental importance': AM Honoré, 'Hedley Byrne \& Co Ltd v Heller \& Partners Ltd' (1965) 8 JSPTL (ns) 284, 298. The tendency to treat negligent misstatement as a distinct category of negligence case is particularly apparent in the United States, but judges and commentators in the Commonwealth also frequently do this: see, eg, the title of the anniversary collection (Barker et al (n 10)), and of some of the chapters in it; Customs and Excise Commissioners (n 9) [35] (Lord Hoffmann); and NRAM Ltd v Steel (Scotland) [2018] UKSC 13, [2018] 1 WLR 1190. This tendency is best understood as a vestige of older, more primitive, ways of thinking about negligence, where the focus was on how the damage or loss came about, rather than questions of more fundamental significance, such as the nature of the damage, the difference between nonfeasance and misfeasance etc. But the misrepresentation category is not only an unsophisticated throwback (like 'liability for animals'), it is also incoherent as employed, since many routine negligence cases that are not treated as misrepresentation cases, including Donoghue $v$ Stevenson, can in fact be analysed in those terms: see Beever, 'The Basis of the Hedley Byrme Action', in Barker et al (n 10) 89.

${ }^{93}$ White (n 26) 257.

${ }^{94}$ Customs and Excise Commissioners (n 9).

95 Indeed the case provides so little clarity on the general question of liability for economic loss that it is best largely to ignore it in that connection. 
determinative of the duty issue, ${ }^{96}$ and described as 'the foundation of this area of law. ${ }^{97}$ As for omissions and intervening conduct cases, there is no doubt that positive obligations can arise in negligence without an assumption of responsibility, ${ }^{98}$ and while I am attracted to the simplicity of Baroness Hale's suggestion (if that is what it was) in Mitchell $v$ Glasgow City Council that the only exception to the general principle of non-liability for the consequences of the deliberate conduct of others should be assumption of responsibility, ${ }^{99}$ it is difficult to square that proposition with cases such as Home Office v Dorset Yacht $\mathrm{Co}_{0}{ }^{100}$ where the Home Office was held liable for the damage done to the yachts by the escaping borstal boys even though it had not taken on a task of any kind for the yacht owners.

Overall, my sense is that in the economic loss context, the results of the cases (if not necessarily the reasoning) are broadly consistent with Lord Goff's claim that assumption of responsibility is generally the determinant of whether a duty of care exists, whereas in the other two types of case assumption of responsibility is only one of a number of broad brush exceptions to the general no-liability rule.

\section{WHY DO WE NEED ASSUMPTION OF RESPONSIBILITY?}

A more neutral framing of my third question would be 'Do we need assumption of responsibility?', but as well as ruining the alliteration in my four questions, I am content to forego neutrality from the off, as I am firmly of the opinion that our law of negligence does indeed need the concept (or at least something like it).

I would make three arguments in defence of the concept. First, in these cases it seems to me that the law is tracking morality. While the couple on the beach are under a moral obligation to protect your child from danger, even before they agree to look after him, that moral obligation is clearly considerably strengthened by their having taken on the responsibility of doing so. ${ }^{101}$ For the law to translate that stronger moral duty into a legal one seems entirely defensible. ${ }^{102}$

The second argument is closely connected to the first. Although I deny below that reliance is a prerequisite of an assumption of responsibility, ${ }^{103}$ the fact that assumptions of responsibility frequently and foreseeably induce reliance - whether on the part of the person to whom responsibility is assumed or a third party - is undoubtedly one of the reasons why they create moral, and legal, obligations.

\footnotetext{
${ }^{96}$ See NRAM (n 92); Banca Nazionale del Lavoro (n 31).

${ }^{97}$ Banca Nazionale del Lavoro (n 31) [7] (Lord Sumption).

98 See, eg, Goldman v Hargrave [1967] 1 AC 645 (PC).

99 [2009] UKHL 11, [2009] 1 AC 874 [76].

100 [1970] AC 1004 (HL).

${ }^{101}$ Imagine, for example, that a friend of theirs arrived, and proposed that they go to the beach café for a drink. While before undertaking their protective task, they were completely free to do so, now one can readily imagine them saying that they cannot, as they are looking after your child and your phone for you.

102 See Lord Reid and Lord Morris's reference to 'moral obligation' in the Hedley Byrne context in Mutual Life \& Citizens' Assurance Co Ltd v Evatt [1971] AC 793 (HL) 812.

103 See text following n 146.
} 
Suppose that having agreed to look after your phone the couple on the beach had failed to safeguard it, and it had been stolen. You could legitimately complain that had they not assumed the responsibility of looking after it - and, implicitly, of doing this with due care - then you would either have foregone your swim, or asked another person, who most likely would have taken better care of it. As a result of your reliance on them, you are therefore left worse off than you would have been had they not assumed responsibility. In theory, the law could respond to this concern in such a case not by recognising the assumption of responsibility as itself the source of an obligation, but instead by requiring you to demonstrate that you or a third party did in fact rely on the assumption of responsibility to your detriment. However, it again seems perfectly sensible for the law not to require this, but instead to treat the assumption of responsibility as a freestanding source of obligation, albeit one justified, in part, by the fact that such assumptions of responsibility are often accompanied by reliance.

The third argument rests on the fact that the most important reason for limiting our core negligence obligations is to protect our freedom of action. A generalised obligation to take reasonable steps to confer benefits on others or to safeguard their economic interests is a much greater threat to our autonomy than a minimalist duty not to injure them or their property through our positive conduct. However, much of the force of this concern is lost in cases where we have chosen to assume a responsibility to another person, ${ }^{104}$ particularly since we have seen that the law allows us to make clear that no liability is to attach to it, and also to limit its scope in three different respects (for whom we undertake it, what we undertake to do, and the standard of care to be expected of us in undertaking it).

Now, none of these arguments in defence of the assumption of responsibility concept is definitive, and of course it can be argued that, unless B has provided consideration, then A should owe no legal obligation in respect of B's economic interests and so forth. This is essentially the view of Tony Weir, who heartily disapproved of Hedley Byrne, ${ }^{105}$ and is also the position adopted by David Campbell in the anniversary collection. ${ }^{106}$ This position essentially rests on the assertion (for that is all it really is) that unless one has oneself paid for information, advice or a service, one should have no legal right to care in its provision. As Tony Honoré pointed out, faced with such a claim, there is no right or wrong answer - 'one can merely make a declaration of faith'. ${ }^{107}$ However, it seems to me (as it did to Honoré) that, all in all, the rule of liability is preferable. ${ }^{108}$ Furthermore, that seems also to be the view taken in all legal systems of which I have a passing knowledge. And nor should we forget that this kind of contractual libertarianism is also impossible to reconcile with a raft of other deeply embedded private law institutions, including fiduciary obligation and the trust.

\footnotetext{
104 See also Sandy Steel, 'Rationalising Omissions Liability in Negligence' (LQR, forthcoming) [19].

105 See Weir, 'Liability for Syntax’ (n 50) 218.

106 David Campbell, 'The Curious Incident of the Dog that did Bark in the Night-Time: What Mischief does Hedley Byrne v Heller Correct?' in Barker et al (n 10).

${ }^{107}$ Honoré (n 92) 299.

108 ibid.
} 
Another line of attack on the assumption of responsibility concept is to argue that while liability should perhaps be imposed in some or all of the cases in question, this should be done on a different basis. One possible alternative ground of liability might be thought to be contract, but it will become apparent from my response to the fourth question that that is not a plausible solution. A second alternative is to try to integrate such cases into the tort mainstream, by renouncing assumption of responsibility and instead determining the duty issue by reference to an approach of universal application. Two such approaches have been suggested in the academic commentary. One rests on proximity, and is associated with the so-called Caparo 'three-stage test'. The other is a multi-factorial policy-based approach, in which the policy arguments for and against liability are weighed in the balance. Both approaches find their supporters in the anniversary collection on Hedley Byrne, ${ }^{109}$ and both rest on the premise that assumption of responsibility as used by the courts is a mere 'foil' or 'veil' for something else (either 'proximity', or alternatively policy considerations) that supposedly provides the real explanation for the results in the cases. ${ }^{110}$ Needless to say that premise is sharply at odds with my argument in this article that, properly understood, assumption of responsibility is a perfectly meaningful concept.

Quite apart from being based on a false premise, these alternatives have little to commend them, as Allan Beever demonstrates in his merciless attack on them in the anniversary collection. ${ }^{111}$ Unlike assumption of responsibility, proximity is a genuinely meaningless concept in this context, with the result that its use to determine duty of care questions is a recipe for ad hoc decision-making unconstrained by principle or precedent. And a multi-factorial policy-based approach is subject to the same objection, with the added disadvantage that the spurious and frequently ill-informed 'policy' argumentation that it generates serves only to make the litigation created by the resultant uncertainty longer and more expensive to resolve. ${ }^{112}$ Anyone who believes that these approaches are preferable to the use of the assumption of responsibility doctrine should read the chapters in the anniversary collection on the law of negligent misstatements in Australia, Canada and New Zealand, all of which have succumbed to varieties of these alternatives, and in all of which the result seems to be an unholy mess.

\section{WHERE DOES ASSUMPTION OF RESPONSIBILITY BELONG?}

\footnotetext{
109 In support of the proximity/three-stage test approach, see Andrew Robertson and Julia Wang, 'The Assumption of Responsibility', and Christian Witting, 'What are We Doing Here? The Relationship Between Negligence in General and Misstatements in English Law', both in Barker et al (n 10). And in favour of a multi-factorial policy analysis, see Kit Barker, 'Negligent Misstatement in Australia-Resolving the Uncertain Legacy of Esanda' in the same collection.

110 See, eg, Barker, 'Unreliable Assumptions in the Law of Negligence' (n 83) 483 (policy concerns).

111 Beever, 'The Basis of the Hedley Byrne Action', in Barker et al (n 10) 91-98. Little is to be gained from my repeating Beever's critique, but there is no doubt that the positive case for assumption of responsibility I put forward here is considerably strengthened by the reasons he gives for rejecting the core negligence analysis.

112 In his chapter in the anniversary collection, Barker lists no fewer than nine separate policy concerns that he believes the courts should take into account when determining the duty question in negligent misstatement cases, and doubtless there are others the courts could add to the mix: Kit Barker, 'Negligent Misstatement in Australia-Resolving the Uncertain Legacy of Esanda' in Barker et al (n 10) 324.
} 
That brings me to my final question, which is perhaps the most intriguing of all. Its importance lies not in the quest for taxonomical order per se, but in the fact that a proper appreciation of the place of assumption of responsibility within private law will better enable us to understand the concept and its implications.

If we turn to the academic commentary on this question for help, the first thing we notice is the extent to which the reductive contract/tort dichotomy continues to exert a quite extraordinary hold over the common law imagination. The continuing tendency to assume that common law obligations must fall into the categories of contract or tort is apparent in the efforts of commentators to explain away assumption of responsibility cases as either core negligence cases, or as contract cases in disguise. Unfortunately this makes it harder to 'extract its rules and peculiarities untrammelled by false equations and superficial resemblances to other concepts'.113

On the tort front, the 'core negligence' view of assumption of responsibility holds that there is no fundamental difference between these cases and negligence cases where liability is based on Donoghue $v$ Stevenson. ${ }^{114}$ This view is encapsulated in Andrew Robertson and Julia Wang's conclusion in their essay in the anniversary collection that 'assumption of responsibility is not a distinctive category of obligation, but simply a particular manifestation of [Lord Atkin's] neighbour principle. ${ }^{115}$ Since I have already identified a number of distinctive features of assumption of responsibility as the foundation of duties of care, it will be readily apparent why I regard this view as untenable.

That is not, however, the only difficulty that the core negligence view faces. There is also the question of fit with the case law. Proponents of the core negligence view have argued that the results in the cases in this area are explicable in proximity terms, but the argument is unpersuasive. ${ }^{116}$ Why, for example, was there no 'proximity' in Caparo $v$ Dickman, ${ }^{117}$ or in Williams $v$ Natural Life Health Foods, ${ }^{118}$ or in Customs \& Excise Commissioners v Barclays Bank $?^{119}$ Efforts to explain away key features of the case law, such as the ability of a defendant to avoid legal liability by an appropriate disclaimer, in core negligence terms are also unconvincing. It has been argued, for example, that this can be explained on the basis that in a negligent misstatement case

113 Norman Palmer, 'Gratuitous Bailment-Contract or Tort?' (1975) 24 ICLQ 565, 572 (writing of bailment). See also Warren L Shattuck, 'Gratuitous Promises-A New Writ' (1937) 35 Mich L Rev 908, 942 fn 103 ('Mere misbranding is of itself unimportant. It matters little what a thing is called so long as its characteristics are understood and it is handled accordingly. But all too frequently a misnomer covers a failure to so understand and a long train of mischief results.').

114 Donoghue (n 34).

115 Robertson and Wang, 'The Assumption of Responsibility' in Barker et al (n 10) 82. This view is not new, but is observable in the early commentary on Hedley Byrne: see Mitchell (n 1) 187.

${ }^{116}$ For a convincing critique, see Beever, 'The Basis of the Hedley Byrne Action', in Barker et al (n 10) 91-94.

117 Caparo (n 8).

118 Williams (n 42).

119 According to Longmore LJ in the Court of Appeal in Customs \& Excise Commissioners, the relationship between the parties was 'about as proximate as one can envisage' ([2004] EWCA Civ 1555, [2005] 1 WLR 2082 (CA) [30]). 
the fact of a disclaimer makes the claimant's reliance unreasonable, ${ }^{120}$ but this is utterly unconvincing. The claimants in Hedley Byrne were hard-headed business people who enquired about the creditworthiness of a client from the client's bankers and who themselves made clear (through their agents) that the enquiry was 'without responsibility'. It is very odd to suppose that it was for that reason unreasonable of them to have relied on any information or advice the bankers provided. If that were true, then only an idiot would have made the enquiry in those terms in the first place. ${ }^{121}$ And the attempt to explain away in the same manner the exclusion from the scope of the Hedley Byrne principle of advice given on a social or informal occasion is open to the same objection. There is nothing 'unreasonable' about relying on advice given on such occasions. If there were, why would people routinely ask for and offer it? Nearly half a century ago Joseph Raz gave an example that reveals how misguided these kinds of argument are. ${ }^{122}$

In his essay in the anniversary collection, Beever leaves the core negligence view of assumption of responsibility in a heap of smoking ruins. However, he falls into the opposite trap of trying to force assumption of responsibility into a contractual straightjacket, an approach I also find unpersuasive (albeit less damaging). ${ }^{123}$ The 'contract view' of assumption of responsibility conceives the concept as contract minus consideration, and for scholars - such as Beever - who see no need for consideration, the conclusion that cases of this kind should be assimilated into contract naturally follows. However, the exclusive focus on consideration is unwarranted, since this is by no means the only problem with a contract analysis. On the contrary, there is another, arguably more fundamental, objection to the contract view of assumption of responsibility, which is that while a contract is an agreement formed by communicative acts ('offer' and 'acceptance'), an assumption of responsibility does not require any kind of communication between the parties at all, and can generate new duties without the beneficiary of those duties even being aware of it. ${ }^{124}$ (Was there really a 'contract' in any possible sense, for example, with the ten-month-old baby who was taken into care in Barrett $v$ Enfield?) Nor are the differences between contract and assumption of responsibility limited to the circumstances in which the new obligations arise. There are also different defences, different privity rules, different remedies and so on. ${ }^{125}$

\footnotetext{
${ }^{120}$ See, eg, Robertson and Wang, 'The Assumption of Responsibility' in Barker et al (n 10) 63-64.

121 The same point can be made in response to Kit Barker's claim that the presence of a disclaimer indicates that the defendant did not intend the claimant to rely on the statement (Barker, 'Negligent Misstatement in Australia-Resolving the Uncertain Legacy of Esanda' in Barker et al (n 10) 338). This is quite simply a non-sequitur. And again, if it were true, why make the statement at all?

122 Joseph Raz, 'Voluntary Obligations and Normative Powers' (1972) 46 Proceedings of the Aristotelian Society, Supplementary Volumes 79, 99.

123 The contract minus consideration analysis is particularly associated with Lord Devlin's speech in Hedley Byrne, where he famously referred to relationships 'equivalent to contract' (Hedley Byrne (n 2) 530), a German concept (see Honoré (n 92) 295-296) not well suited to the common law. However, the intellectual origins of the contract view pre-date Hedley Byme: see Mitchell (n 1) 194-195.

${ }^{124}$ Beever's position is at least consistent, since he believes (wrongly, in my view) that assumption of responsibility necessarily involves a communication from the defendant to the claimant: Beever, Rediscovering the Law of Negligence (n 45) 308.

125 See Stevens (n 13) 33.
} 
There is no doubt that the case law in this area is shot through with ideas that we tend to associate with contract, such as the avoidability of the obligation, notions of privity, intention to create legal relations, disclaimers, non-delegable duties and the like. Furthermore, as we have seen, analogies with contract are frequently illuminating in this context. But that is a far cry from the conclusion that the liability in question is best understood as contractual in nature. As Lord Sumption said in the Banca Nazionale del Lavoro case, it 'does not follow from the fact that a noncontractual relationship ... is as proximate as a contractual relationship, that it is legally the same as a contractual relationship or involves all of the same legal incidents'. ${ }^{26}$

One consequence of contract/tort reductionism in this context is the tendency to miss the connections between assumption of responsibility and the law relating to fiduciaries. Those connections were emphasised by Lord Reid in Hedley Byme, and by Lord Browne-Wilkinson in Henderson and White. And the similarity between Lord Goff's reformulation of the assumption of responsibility concept and standard definitions of fiduciary relationships is certainly striking. ${ }^{127}$ But, as with contract, the resemblances between these concepts should not be mistaken for equivalence, nor the differences between them ignored. ${ }^{128}$

The truth is that, as Paul Mitchell has pointed out, 'assumption of responsibility [predates] categorisation into contract and tort, and [cannot] sensibly forced into either category'. ${ }^{129}$ The concept should instead be understood as a sui generis source of legal obligation, connected to, but distinct from, core tort, contract and fiduciary duty. ${ }^{130}$ Such an understanding of gratuitous undertakings and bailment was commonplace among scholars of earlier generations, such as Joseph Beale ${ }^{131}$ and Percy Winfield. ${ }^{132}$ And in more recent times, similar views have been expressed in respect of bailment by Norman Palmer. ${ }^{133}$ It is no coincidence that the works of these scholars are informed by a deep knowledge of our legal history, since, as Winfield pointed out, the nineteenth-century contract/tort dichotomy 'deliberately

\footnotetext{
126 Banca Nazionale del Lavoro (n 31) [13] (Lord Sumption).

127 Compare Spring (n 43) 318 (Lord Goff) with, for example, the definitions cited by Robert Flannigan, 'The Fiduciary Obligation' (1989) 9 OJLS 285, 306-307.
}

128 At a definitional level, the key difference seems to be that, while both concepts involve 'A taking on a task for or on behalf of B', in the case of fiduciary obligation there is the important added element that in the performance of that task A must exercise a power or discretion the exercise of which will affect B's interests. This also has the effect of making B particularly vulnerable in the fiduciary situation. The law responds to these distinctive features of fiduciary relations by imposing a stringent set of duties on the fiduciary over and above a duty of care, and by backing these up with some equally stringent remedies.

${ }^{129}$ Mitchell (n 1) 195.

${ }^{130}$ For an early suggestion that Hedley Byrne (n 2) might best be understood in these terms, see Robert Stevens, 'Hedley Byrne v Heller: Judicial Creativity and Doctrinal Possibility' (1964) 27 MLR 121, 161.

${ }^{131}$ Beale (n 1) 225 ('another division of personal rights, co-ordinate with torts and contracts'). See also Shattuck (n 113) 942.

132 PH Winfield, The Province of the Law of Tort (CUP 1931) ch 5.

133 Palmer (n 113). See also Yearworth v North Bristol NHS Trust [2009] EWCA Civ 37, [2010] QB 1 [48] (Lord Judge CJ); CHS Fifoot, History and Sources of the Common Law (Stevens \& Sons 1949) 24; GW Paton, Bailment in the Common Law (Stevens \& Sons 1952) 3, 29; and Bell (n 14). 
ignore[d]' that history. ${ }^{134}$ By contrast, much of the recent scholarship on assumption of responsibility is sorely lacking in historical perspective, and misunderstands Hedley Byrne because it views the case against 'an oversimplified, reductive and unhistorical background of the law of obligations'.

\section{THREE RED HERRINGS}

That concludes my discussion of the four questions I have posed about assumption of responsibility, but I would now like to highlight three distractions which have served to obscure the real meaning and significance of the concept.

\section{Special skill or knowledge}

The first red herring is the idea that the defendant must have some special skill or knowledge for the assumption of responsibility analysis to hold. The origins of this meme lie deep in our legal history, ${ }^{136}$ and it is clearly observable in the speeches in Hedley Byrne. But it seems to me that in the modern law the defendant's skill and knowledge is really of relevance at the breach stage of the negligence enquiry, rather than the duty stage. ${ }^{137}$ When it comes to deciding whether the defendant has been negligent in an assumption of responsibility case, we have seen that any special skill or knowledge that she held herself out as having is relevant in determining the standard of care against which her conduct will be measured. However, apart from its possible second-order significance as a consideration in the intention to create legal relations' enquiry, ${ }^{138}$ there is no reason why the defendant's specialist expertise should be relevant to the question of whether there was an assumption of responsibility in the first place. In any case, this requirement need not concern us unduly since in Spring $v$ Guardian Assurance Lord Goff watered it down to such an extent ${ }^{139}$ that it no longer seems to operate as a substantive limit on the scope of the assumption of responsibility concept, even in economic loss cases. ${ }^{140}$

\section{Voluntariness}

Much ink has been spilt on the question of whether or not the obligations to which an assumption of responsibility gives rise are properly described as voluntary obligations, but the debate is not particularly illuminating, both because the protagonists clearly have very different ideas of what a voluntary obligation is, and because it is not entirely clear why it matters anyway.

\footnotetext{
134 Winfield, The Province of the Law of Tort (n 132) 64.

135 Mitchell (n 1) 197.

136 See AW Brian Simpson, A History of the Common Law of Contract (Clarendon Press 1975) 229, 233.

${ }^{137}$ For judicial analysis of the issue consistent with this claim, see, eg, Mutual Life (n 102) 803-804 (Lord Diplock). And for a similar argument, see Whittaker (n 61) 178-179.

138 See Hedley Byrne (n 2) 531 (Lord Devlin).

139 Spring (n 43) 320. See also Henderson (n 21) 180 (Lord Goff).

140 See, eg, Lennon v Metropolitan Police Commissioner [2004] EWCA Civ 130, [2004] 1 WLR 2594.
} 
One of the reasons why the debate has arisen is that critics of the assumption of responsibility concept seem to assume that if they can show that the obligations to which assumptions of responsibility give rise are not (in their terms) 'voluntary' then they have demonstrated both that there is no meaningful distinction between those obligations and those imposed by core negligence law, and that there is no good reason for the law to impose obligations on an assumption of responsibility basis. ${ }^{141}$ But neither claim is correct. We have already seen that there are many quite concrete distinctions between the duties of care that arise out of assumptions of responsibility and those that are imposed by core negligence law, and the existence of those distinctions does not depend on the former being voluntary obligations and the latter not. (It may be that some of those distinctions point to the conclusion that the former are indeed properly described as voluntary obligations, but that is of course a very different question.) Furthermore, in answer to my second question, I identified three good reasons why the law is justified in employing the assumption of responsibility concept to determine whether duties of care exist, none of which rests on the premise that the obligations to which an assumption of responsibility give rise are correctly described as voluntary (though again, the third reason points to the conclusion that they are). Once again, the analogy with contract is helpful. Contractual obligations may or may not be properly described as voluntary, but if (according to the definition of voluntary we are employing) we arrive at the conclusion that they are not, it does not follow either that there is no meaningful distinction between contract and tort, nor that there is no there is no good reason for the law to impose obligations on the basis that they arise out of a contract between the parties.

The focus on voluntariness has also given rise to the very damaging idea that an assumption of responsibility must be the result of a free choice on the defendant's part. While I am happy to accept that no duty of care would arise out of an assumption of responsibility that was the result of, say, duress, it is a serious error to suppose that for the concept to apply A must have a free choice whether to take on a task or job for B, unconstrained by A's existing obligations. It is therefore most unfortunate that the contrary has sometimes been assumed by commentators seeking to undermine the concept ${ }^{142}$ and by judges who have held that the conduct of a public authority which is acting pursuant to a statutory duty cannot constitute an assumption of responsibility since it was obliged so to act as a matter of public law. ${ }^{143}$ Not only is this argument impossible to square with the case law - see, for example, Barrett v Enfield - but it also rests on a false premise about the nature and significance of assumed obligations. A's decision to buy the last remaining bottle of Dow's 1871 Vintage Port from B is still binding even if A has previously contracted to sell such a bottle to $\mathrm{C}$, and so has no real choice but to enter the transaction. And a public authority that argued that it could renege on its contractual commitments because they were entered into in pursuance of its statutory obligations would rightly be laughed out of court.

\footnotetext{
${ }^{141}$ See, eg, Robertson and Wang, 'The Assumption of Responsibility' in Barker et al (n 10) 56-57.

142 See, eg, ibid 59, 65.

143 See Nolan, 'The Liability of Public Authorities for Failing to Confer Benefits' (n 39) 283-284 (and cases there cited). See also the criticism of this idea by Tom Cornford, 'Assumption of Responsibility by Public Authorities' (2018) 30 Denning LJ 55, 78-79.
} 
Although I regard discussions of the voluntariness of assumed obligations as largely a distraction, I should emphasise that I am perfectly content to describe these obligations as voluntary, while recognising that of course it all depends on what we mean by such a claim. ${ }^{144}$ At a basic level, such a description is consistent with the fact that the obligations arise out of the defendant's taking on the task or job in question, so that, unlike core negligence obligations, they are the avoidable result of A's voluntary conduct. And if we want to employ a more sophisticated analysis, we can turn to the work of Raz, who identifies three characteristics of voluntary obligations properly so called: (1) that the person undertaking the obligation is aware of its normative implications; (2) that the person can avoid those implications; and (3) that the person's belief that he will incur an obligation by his action is a positive reason for holding him bound by it. ${ }^{145}$ Since all three of those conditions would appear to be satisfied in this context, it follows that the obligations to which an assumption of responsibility gives rise can properly be described as voluntary in the Razian sense. And note that, if that is right, then it provides us with another distinction between these obligations and core negligence obligations (which are clearly not voluntary in this sense), as well as with a fourth possible reason for recognising assumption of responsibility as a source of obligations, namely Raz's argument that by enforcing voluntary obligations the law both recognizes and reinforces the social practice of undertaking them. ${ }^{146}$

\section{Reliance}

Finally, I come to the most pervasive and significant of the three red herrings, namely the idea that an assumption of responsibility requires some sort of reliance on the part of the claimant. The specific origins of this idea lie in the fact that the modern concept of assumption of responsibility derives from the decision in Hedley Byme, a case concerned with a statement made by the defendant (A) to the claimant (B). In cases of this kind, B's reliance on the statement is of course required for it to cause her the loss necessary to render the statement actionable in negligence. However, the fact of B's reliance (in this sense) cannot determine the question of whether there was a prior assumption of responsibility by $\mathrm{A}$ towards $\mathrm{B}$, since by definition such reliance occurs after the statement is made, and therefore, after the assumption of responsibility takes place. ${ }^{147}$ Rather, reliance plays a primarily causal

144 Critics of assumption of responsibility tend to employ definitions of voluntary obligation so narrow that they would not even encompass contractual obligations. Hence the claim that an obligation is only voluntary 'in a meaningful sense' if it represents the manifestation of a person's subjective will or intention (see, eg, Barker, 'Negligent Misstatement in Australia-Resolving the Uncertain Legacy of Esanda' in Barker et al (n 10) 323-324; Witting, 'What are We Doing Here? The Relationship Between Negligence in General and Misstatements in English Law' in Barker et al (n 10) $236 \mathrm{fn}$ 98), which smacks of the long discredited will theory of contract.

145 Raz, 'Promises in Morality and Law' (n 59) 929.

146 ibid 933.

${ }^{147}$ For the same reason, whether the reliance was reasonable cannot logically be relevant to whether a duty of care arose, though it may have a bearing on issues of legal causation and contributory negligence. Nevertheless, courts and commentators sometimes fall into the trap of asserting that the existence of a duty is or should be dependent on the reasonableness of the claimant's reliance: see, eg, NRAM (n 92) [32], [35] (Lord Wilson); Barker, 'Negligent Misstatement in Australia-Resolving the Uncertain Legacy of Esanda' in Barker et al (n 10) 338. Note that I am not denying that a reliancebased test can serve as the touchstone of duty in the negligent misstatement context; on the contrary, this is (unfortunately, in my view) the position in many common law jurisdictions. But such a test 
role in misstatement cases of this kind, with the caveat that the foreseeability of reliance by $\mathrm{B}$ is also necessary for $\mathrm{A}$ to have breached any duty owed to $\mathrm{B} .{ }^{148}$

In assumption of responsibility cases not involving negligent misstatements, reliance in this straightforward, causal, sense, is of course unnecessary. And yet when Lord Goff sought to extend the Hedley Byme principle beyond misstatements in the 1990s, he tried to hold on to the connection with reliance by using the word in its weaker, more passive sense of 'hope or expectation', as when he spoke of the claimant's relying 'on the defendant to exercise due care and skill'. ${ }^{149}$ This was an unhelpful distraction, not least because in this weaker sense, reliance appears to have no normative significance. ${ }^{150}$ Then again, it seems not to cause a great deal of trouble in practice in the professional negligence context, where there is usually a degree of mutuality between the parties, with the result that this weak requirement of reliance rarely poses much of a problem for claimants.

However, in recent times, the focus on reliance in the professional negligence context has increasingly begun to influence judicial reasoning in assumption of responsibility cases involving omissions and third parties. In such cases, the better view is that no reliance, in any sense, is required. Hence in the beach story, the doctor owes you a duty of care by virtue of her assumption of responsibility even though you are unconscious and completely unaware of her involvement. ${ }^{151}$ This view is consistent with both of the Barrett cases, one of which (Barrett $v$ Ministry of Defence ${ }^{152}$ ) involved assistance given to a serviceman rendered insensible by drink, and the other of which (Barrett $v$ Enfield) involved, as we have seen, the taking into care of a ten-month old baby. ${ }^{153}$ And - as Robert Stevens points out ${ }^{154}$ - it is also consistent with the authorities on sub-bailment, and the obligations that attach to

must logically be founded not on the fact of (reasonable) reliance, but on the fact that $\mathrm{A}$ intended $\mathrm{B}$ to rely, invited B to reply, should have foreseen that B would rely, etc.

148 These points are made very clearly by Lord Browne-Wilkinson in White (n 26) 272.

149 Spring (n 43) 318 (Lord Goff). See also Henderson (n 21) 180, where Lord Goff highlights the shift in meaning.

${ }^{150}$ As Weir wrote, the change of meaning 'rob[s] the idea of all utility': Tony Weir, An Introduction to Tort Law (2nd edn, OUP 2006) 38. See also Whittaker (n 61) 181 (reliance plays 'no real restrictive role' outside the misstatement context).

151 Banbury v Bank of Montreal [1918] AC 626 (HL) 689 (Lord Atkinson). See also Hedley Byrne (n 2) 495 (Lord Morris); and Watson (n 24) [48] (Lord Phillips MR) (accepting that reliance was not required for a doctor-patient relationship - and the positive obligations entailed by it - to come into existence). The fact is that every day of the year hospitals come under positive obligations to unconscious persons whom they accept as patients.

152 Barrett v Ministry of Defence (n 87).

153 See also Chandler (n 3), where there was no evidence of reliance either by the claimant or the subsidiary; and (more emphatically) Biddick (n 5). And for explicit judicial acknowledgement of the distinction between negligent misrepresentation cases and omissions cases in this regard, see Sherratt (n 39) [82] (King J). Commentators reluctant to accept that assumption of responsibility alone can give rise to positive obligations sometimes attempt to explain the outcomes in such cases by arguing that in fact there was some form of reliance by B or a third party, and that this explains why A is liable: see, eg, Nicholas J McBride and Roderick Bagshaw, Tort Law (6th edn, Pearson 2018) 213-215. The trouble with this is, first, that the argument is speculative (there might have been reliance, but this cannot actually be demonstrated), and secondly, that this is clearly not the basis on which liability was imposed in these cases.

154 Stevens, Torts and Rights (n 13) 11. 
finders of property. In neither case need the owner of the property even be aware of the sub-bailment or finding for the obligations owed to her to arise. Indeed, as Stevens also points out, it is a general characteristic of the rights created by noncontractual undertakings that the beneficiary need have no knowledge of the right. ${ }^{155}$

It is worth emphasizing what is at stake here. The idea that reliance is somehow required for an assumption of responsibility analysis to hold in, say, a rescue case is not a minor gloss on the concept but threatens completely to undermine its significance as a distinctive source of legal obligation in this context. This is because, if the ground of liability is not the defendant's undertaking, but the fact that the claimant or a third party has relied on it to the claimant's detriment, then the case ceases to be a true omissions case at all, and the defendant's liability can readily be explained under the core Donoghue $v$ Stevenson principle. ${ }^{156}$ And so it is precisely in the case where there is no reliance that the assumption of responsibility concept assumes its greatest importance.

Finally, note that the rejection of reliance as a prerequisite of an assumption of responsibility analysis is not inconsistent with my earlier claim that the likelihood of reliance (either by the claimant or a third party) is a good reason for the law to attach significance to assumptions of responsibility in the first instance. After all, I also argued that there were other reasons for the law to do that, and besides there are lots of possible justifications for the law choosing to relieve the claimant of the burden of establishing reliance on the facts of each particular case. ${ }^{157}$

\section{CONCLUSION}

To conclude I wish to make five additional observations about a topic the complexity and significance of which I have been unable to do justice to in the space available.

The first observation is that I believe that our courts will soon be required to address the question of whether it is possible for a defendant to assume a responsibility not just to an identifiable individual or group - such as, perhaps, all those on the beach in the case of the lifeguard - but to the entire community (what Blackstone called a 'general undertaking ${ }^{158}$ ). There is a clear connection here with the ancient idea of the common calling. ${ }^{159}$ For example, there is arguably an analogy between the brightly lit

\footnotetext{
155 ibid 10.

156 See Nolan, 'The Liability of Public Authorities for Failing to Confer Benefits' (n 39) 273-278.

${ }^{157}$ I would not wish to exclude the possibility that, like special skill or knowledge, reliance may have a second-order significance in this context. It is possible, for example, that the vexed question of when A can withdraw from a prior assumption of responsibility towards B could be resolved by making the withdrawal contingent on either A establishing that neither B nor a third party had relied on it to B's detriment, or compensating B for any loss suffered as a result of such reliance: see ibid 282-283.

158 III Bl Comm 164 (also referring to a 'universal assumpsit'). See also Roderick Bagshaw, 'The Duties of Care of Emergency Service Providers’ [1999] LMCLQ 71, 82-85.

159 For useful discussion of the common calling idea, see Charles K Burdick, 'The Origin of the Peculiar Duties of Public Service Companies: Part I' (1911) 11 Col L Rev 514. As Burdick points out, by holding himself out to serve the public generally, a person assumed two obligations: 'to serve all who should apply and to serve with care' (at 522).
} 
signs announcing the presence of an Accident \& Emergency Department in an NHS hospital and the signs still hung outside inns, which for centuries the courts have interpreted as representing a commitment to provide shelter and sustenance to passing travellers. ${ }^{160}$ An analysis along these lines might provide a suitable solution to the vexed question of emergency services liability, which currently threatens to collapse into a case-by-case scrutiny of the precise words used by 999 call handlers, ${ }^{161}$ a development which could result in those handlers being instructed by their employers to say as little as possible, to the potential detriment of the distressed individuals on the other end of the line. ${ }^{162}$

Secondly, I stand by my suggestion in an earlier article that in cases of acquired rights arising out of an assumption of responsibility, the defendant really is under a legal obligation to take care, so that the negligence is itself the wrong. ${ }^{163}$ This can be contrasted with the position in core rights cases - which is to say those where negligence liability is not based on a prior relationship between the parties - where there is in fact no legal 'duty of care' at all, but rather a duty not to negligently injure. If that is correct, then it follows that in assumption of responsibility cases the wrong is done not when loss or damage is suffered, but when the negligent conduct takes place. Were the courts to accept this, they would rid themselves of the impossible task of pinpointing the moment at which 'damage' occurs in economic loss cases, ${ }^{164}$ as well as eliminating at a stroke the absurdity of applying different limitation rules to the same breach of the same obligation in professional negligence cases, depending on whether the claim is framed in contract or tort.

Thirdly, while I have attempted in this article to identify general principles of assumption of responsibility that apply to all such cases, I am conscious that in doing so I may have succumbed to what Lord Goff called 'the temptation of elegance', ${ }^{165}$ and that assumption of responsibility may better be understood as a looser, more flexible concept, which, though underpinned by some common essentials, plays out differently in different contexts. It may well be, for example, that while reliance is not relevant in omissions and third party cases, it is (in some form) a prerequisite of liability in the economic loss context, and that conversely the ability of a potential defendant to disclaim legal responsibility, and to tailor the scope of the obligation, is more pronounced in economic loss cases than in other situations. Furthermore, the duty of care in bailment may be better understood as resting on principles that are distinct, albeit closely analogous to those in play in other

160 See, eg, Constantine v Imperial Hotels Ltd [1944] KB 693 (KBD). For the analogy, see also Stevens, Torts and Rights (n 13) 11.

161 See, eg, Sherratt (n 39).

162 See Michael (n 37) [165], [167] (Lord Kerr); and Cornford (n 143) 72 (both arguing that it makes no sense to rest liability on such niceties). Cornford appears to be supportive of what would in effect be a 'general undertaking' approach in all public authority cases (67-68).

163 Donal Nolan, 'Deconstructing the Duty of Care' (2013) 129 LQR 559, 587. This was the understanding in the early nineteenth century: see, eg, Howell v Young (1826) 5 B \& C 259, 108 ER 97 (the negligence of an attorney was the gist of the action, from when time began to run for limitation purposes, regardless of whether the claim was brought in contract or tort).

164 As to which, see Donal Nolan, 'Rights, Damage and Loss' (2017) 37 OJLS 255, 263-264 (and authorities there cited).

${ }^{165}$ Robert Goff, 'The Search for Principle’ (1983) 69 Proceedings of the British Academy 169, 174. 
assumption of responsibility cases. ${ }^{166}$ But Honoré was surely right to say that the common law should 'aim at a certain generality', ${ }^{167}$ and it is that aspiration which explains my reluctance to adopt a more fine-grained or context-specific approach than is obviously necessary.

My fourth observation is that our judges deserve considerable credit for sticking with the assumption of responsibility concept in the face of fairly consistent hostility directed at it by academic commentators. The House of Lords in Hedley Byrne may only have 'seen through a glass, darkly', but they saw nonetheless, and Lord Goff did our law of negligence a great service by rescuing the concept when it was imperilled, and by clearing away much of the grime on the glass. What is more, the modern vitality of the concept demonstrates that our judiciary continue to recognise its explanatory and normative force, and experience in jurisdictions that have renounced it in favour of alternative approaches strongly suggests that they are right to do so.

Finally, as that last observation suggests, I have to admit to a certain degree of frustration with much of the recent scholarship on this question, which to my mind takes a somewhat narrow and blinkered view of the law, and lacks a broader perspective informed by legal history and the work of our scholarly predecessors. Were the blinkers to be removed, and the perspective broadened, I firmly believe that scholars would stop arguing about whether or not assumption of responsibility is a meaningful and distinctive basis of legal obligation, and instead move on to a more productive discussion as to what exactly it means and why precisely it is distinct.

166 That negligence liability has some distinctive features in the case of bailment is undeniable, the most obvious being the reversal of the burden of proof as to fault. See further, Bell (n 14) 474-484 (though many of the examples he gives are characteristic of assumed duties of care generally).

167 Honoré (n 92) 299. 